\title{
Dong-Won $\mathrm{Oh}^{1}$, Yong-Seop Park ${ }^{1}$, Woo-Bung Lee ${ }^{1}$, Mi-Sook Park ${ }^{1}$, Kyoung-Haw Jung ${ }^{1}$ and Jae-Kyeung Park ${ }^{2}$
}

\section{SYN THESIS AND CHARACTERIZATION OF FLUORENE-IMIDAZOLE COPOLYMERS}

\author{
${ }^{1}$ Department of Chemistry Education, Kyungpook National University, \\ Daegu 702-701, Korea; ddk-odw@daum.net \\ 2 Department of $\mathrm{N}$ ano Engineering, Sangju Campus, Kyungpook National University, \\ Sang J u 742-711, Korea
}

Received: M ay 21, 2013 / Revised: J une 03, 2013 / Accepted: August 12, 2013

(c) Oh D.-W., Park Y.-S., Lee W.-B., Park M.-S., Jung K.-H., Park J.-K., 2013

\begin{abstract}
New PAF derivatives [poly(fluorene-co-1,3diphenylimidazolium chloride) 7 and poly(fluorene-co1,3-diphenylimidazol-2-thione) 9] with high thermal stability were synthesized and their physical and optical properties were investigated. The obtained polymers were characterized by ${ }^{1} \mathrm{H}$ NMR, ${ }^{13} \mathrm{C}$ NMR, DSC, TGA, GPC, and SEM-EDX. Thermogravimetric analysis (TGA) showed excellent thermal stability of the resulting polymers. Initial weight loss $(5 \%)$ was observed around $700 \mathrm{~K}$, with the main decomposition occurring around $760 \mathrm{~K}(50 \%)$. The glass transition temperature of 9 was higher than that of the host copolymer 7 . The copolymers in this study emitted in the blue region with a maximum around $440 \mathrm{~nm}$. The emission spectra of copolymer 9 showed a red shift compared to that of the host copolymer 7. The optical band gaps deduced from the onset of the absorption of copolymers were about 3.06 and $2.91 \mathrm{eV}$ for copolymers $\mathbf{7}$ and $\mathbf{9}$, respectively.
\end{abstract}

Keywords: conductive polymer, polyalkylfluorene (PAF), copolymer, imidazol-2-ylidene, carbene.

\section{Introduction}

Conductive polymers are very important compounds widely used in many fields. Recently studies on conductive polymer, on materials for display such as organic EL or organic semiconductors and on applications such as polymer sensors have actively been conducted in addition to studies on applications for static elimination, harmful electromagnetic shielding and absorbents. The characteristics of electric conductive polymers were first discovered in polyacetylene in 1977. After that, studies on various types of conductive polymers such as poly-p-phenylenevinylene (PPV), polythiophene (PTh), polypyrrole, polyvinylcarbazole (PVK), and polyalkylfluorene (PAF) derivatives [1-9] have been conducted in many areas. Since PAF has high thermal and oxidative stability and a variety of substituents can be introduced at the C-9 position, it has many advantages such as increased solubility, easy processing, and diversity and flexibility of molecular design. Thus, it is a compound on which many studies are actively conducted these days.

Carbenes have played an important role as intermediates in organic reactions for a long time. Carbenes are a very highly reactive species, practically all having lifetimes considerably under $1 \mathrm{~s}$ and have been isolated only by entrapment in matrices at low temperatures (77 $\mathrm{K}$ or less) [10]. However, once the stable crystalline carbene, imidazol-2-ylidene derivative (N-heterocyclic carbene), was isolated from the deprotonation of the imidazolium ion in a pure state by Arduengo in 1991 [11], many kinds of stable carbenes have been synthesized in several studies [12-16]. Imidazol-2-ylidene shows extraordinary stability and can be handled under an inert atmosphere at room temperature [12]. The stability of imidazol-2-ylidene can be explained by both electronic and steric effects. The $\pi$ electron provided from the nitrogen atoms bonded to the central atom of the carbene gives it aromaticity which has $6 \pi$-electron systems, and it can be thermodynamically stabilized. Additional stability for the imidazol2 -ylidene electron pair was gained from the $\sigma$-electron withdrawal effects on the carbene center by the more electronegative nitrogen, which led to lower energy of the in-plane carbene orbital. Steric effect also contributed to the kinetic stability of the imidazol-2ylidene. Functional groups that are large in size bonded 
to the nitrogen atom can be stabilized in terms of kinetics by hindering the reaction in the center of the carbene.

Imidazol-2-ylidene is known to have the characteristics of a singlet carbene [13]. The singlettriplet splitting for imidazol-2-ylidene is very large, approximately $79.4 \mathrm{kcal} / \mathrm{mol}$, which is much larger than the splitting for general carbenes (less than $50 \mathrm{kcal} / \mathrm{mol}$ ). The singlet state of imidazol-2-ylidene can give rise to both nucleophilic and electrophilic behavior. Between the two cases, nucleophilic reactivity is dominant because of the high electron density in the center of the carbene [13]. The electron pair of the center of the carbene is not involved in aromaticity and it acts as a nucleophile. The high electron density in the center of the carbene increases the nucleophilicity, but its behavior as an electrophile is disturbed by preventing the approach of other nucleophiles.

As shown in the following reaction, imidazol-2ylidene derivatives were generated from the deprotonation of imidazolium salts by a strong base. In addition, these carbenes can be easily converted to the corresponding products by reacting with sulfur or metalcontaining precursors [17-24].

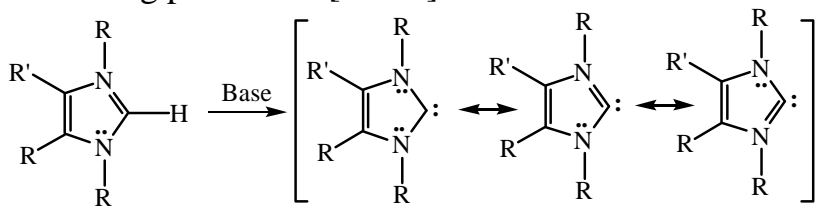

$\mathrm{R}=\mathrm{Ph}$, Adamantyl, $\mathrm{Me}$ $\mathrm{R}^{\prime}=\mathrm{H}, \mathrm{Me}, \mathrm{Ph}$

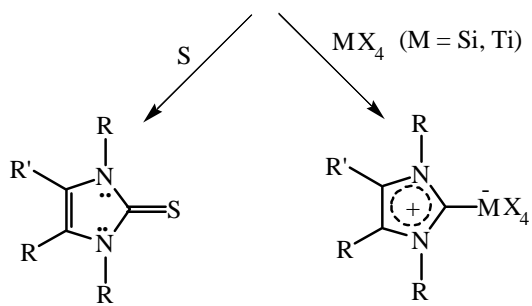

In this study, we synthesized new PAF derivatives [poly(fluorene-co-1.3-diphenylimidazolium chloride) 7 and poly(fluorene-co-1.3-diphenylimidazol-2-thione) 9] with high thermal stability and their physical and optical properties were investigated.

\section{Experimental}

\subsection{Instrumentation}

The molecular weight of the polymers was determined using Water's alliance 2000 gel permeation chromatography (GPC) instrument calibrated with polystyrene standards. $1 \mathrm{H}$ and $13 \mathrm{C} \mathrm{NMR}$ spectra were recorded at $500 \mathrm{MHz}$ on a Varian Unity Inova spectrometer in $\mathrm{CDCl}_{3}$ solution. GC-Mass spectra were obtained using a Shimadzu Corporation QP-1000A spectrometer. Absorption and photoluminescence (PL) emission spectra of the polymers were measured using an Optizen $3220 \mathrm{UV} / \mathrm{Vis}$ spectrophotometer and a spectra pro $2150 \mathrm{i}$ spectrometer, respectively. Thermogravimetric analysis (TGA) and differential scanning calorimetry (DSC) of the polymers were carried out under a nitrogen atmosphere at a heating rate of $10 \% \mathrm{~min}$ using a Setaram, Betsys 24 TG-DTA and Seiko, SSC5200H instruments, respectively. SEM images and EDX spectra of the polymers were obtained using a Hitachi Corporation S-4300 \& EDX-350 instrument, respectively.

\section{2. $M$ aterials}

The reaction precursors, glyoxal $\left[\mathrm{C}_{2} \mathrm{H}_{2} \mathrm{O}_{2}\right] \mathbf{1}$, 4-bromoaniline $\left[\mathrm{C}_{6} \mathrm{H}_{6} \mathrm{BrN}\right] \quad \mathbf{2}$ and $p$-formaldehyde $\left[\mathrm{HO}\left(\mathrm{CH}_{2} \mathrm{O}\right)_{n} \mathrm{H}(n=8-100)\right] \mathbf{3}$, and the monomers, 9,9dioctylfluorene-2,7-diboronic acid bis(1,3-propanediol)ester $\left[\mathrm{C}_{35} \mathrm{H}_{52} \mathrm{~B}_{2} \mathrm{O}_{4}\right] \mathbf{5}$ and 9,9-dioctyl-2,7-dibromofluorene $\left[\mathrm{C}_{29} \mathrm{H}_{40} \mathrm{Br}_{2}\right] \mathbf{6}$, and the two end capping reagents, 2-thiophene boronic acid and 2-(4bromophenyl)-5-phenyl-1,3,4-oxadiazole, were purchased from Aldrich Chemical Co. and used without any further purification.

\subsection{Synthesis}

1,3-bis(4-bromophenyl)imidazolium chloride $\mathbf{4}$ was obtained as previously described [10]. In a nitrogen atmosphere, to a magnetically stirred solution of $p$ formaldehyde $3(0.755 \mathrm{~g}, 25.1 \mathrm{mmol})$ in $15 \mathrm{ml}$ of toluene was slowly added a solution of 4-bromoaniline 2 ( $8.65 \mathrm{~g}$, $50.3 \mathrm{mmol}$ ) in $10 \mathrm{ml}$ of toluene at room temperature, and the reaction mixture was heated to $373 \mathrm{~K}$ until the solid reactants were dissolved. The reaction mixture was cooled to $313 \mathrm{~K}$, and then $4.15 \mathrm{ml}$ of aqueous $6 \mathrm{M} \mathrm{HCl}$ (25 mmol) was slowly added. When the addition was completed, the mixture was stirred for $10 \mathrm{~min}$ before $3.63 \mathrm{~g}(62.9 \mathrm{mmol})$ of $40 \%$ aqueous glyoxal 1 was added. When the glyoxal addition was completed, the mixture was stirred for $10 \mathrm{~min}$ at room temperature, then heated to $373 \mathrm{~K}$ and maintained at that temperature for $2 \mathrm{~h}$. A dark solid formed while the reaction mixture was hot. The reaction mixture was cooled to room temperature. Removal of volatiles under vacuum yielded a dark oily solid. The product was washed with acetonitrile and dried under vacuum to afford $14.1 \mathrm{~g}$ (a yield of $67.8 \%$ ) of a dark solid. Mp: 413-416 K. Mass $\mathrm{m} / \mathrm{z} 379(\mathrm{M}+\mathrm{-Cl}) .{ }^{1} \mathrm{H} \mathrm{NMR}\left(\mathrm{CDCl}_{3}, \mathrm{ppm}\right) \delta: 7.48(d, 2 \mathrm{H})$, 7.71(d, 4H), 7.79(d, 2H), 8.31(s, 2H), 10.13(s, 1H). ${ }^{13} \mathrm{C} \mathrm{NMR}\left(\mathrm{CDCl}_{3}, \mathrm{ppm}\right) \delta: 124.14,125.78,125.83$, $126.28,134.79,135.09,135.81,136.52$.

Polymerization. The copolymer 7 was synthesized by Suzuki cross-coupling polymerization. 
Poly(fluorene-co-1,3-diphenylimidazolium chloride) 7. The phase transfer catalyst, aliquat $336(0.70 \mathrm{~g})$, tetrakis(triphenylphosphine)palladium $(0.02 \mathrm{~g})$ and $2 \mathrm{M}$ aqueous sodium carbonate $(25 \mathrm{ml})$ were added sequentially to a mixture of 1,3-bis(4-bromophenyl)imidazolium chloride 4 (0.370 g, $0.895 \mathrm{mmol})$, 9,9-dioctylfluorene-2,7-diboronic acid bis(1,3-propanediol)ester 5 ( $2.50 \mathrm{~g}, 4.48 \mathrm{mmol})$, and 9,9-dioctyl-2,7dibromofluorene $6(1.964 \mathrm{~g}, 3.582 \mathrm{mmol})$ in $35 \mathrm{ml}$ of toluene under nitrogen. The solution was stirred vigorously and heated under gentle reflux for $1 \mathrm{~h}$ until a viscous reaction mixture was observed. Additional $10 \mathrm{ml}$ of toluene were added, and the reaction was allowed to continue for another $48 \mathrm{~h}$. Subsequently, the polymer was capped by adding $0.05 \mathrm{~g}$ of 2-(4-bromophenyl)-5phenyl-1,3,4-oxadiazole and heating for $6 \mathrm{~h}$, followed by the addition of $0.15 \mathrm{~g}$ of 2-thiophene boronic acid and heating for $6 \mathrm{~h}$. The reaction mixture was cooled to $323 \mathrm{~K}$ and added slowly to a stirred solution containing $500 \mathrm{ml}$ of methanol and $50 \mathrm{ml}$ of deionized water. The polymer fibers were collected by filtration and washed with methanol. The crude product was dissolved in toluene and reprecipitated with methanol-acetone (1:1). The solid material was washed with acetone for $24 \mathrm{~h}$ in a Soxhlet apparatus and dried in a vacuum oven at $333 \mathrm{~K}$ for $24 \mathrm{~h}$. The polymer weighed $2.63 \mathrm{~g}$ (approximately $79 \%$ yield). ${ }^{1} \mathrm{H}$ NMR $\left(\mathrm{CDCl}_{3}, \mathrm{ppm}\right) \delta: 7.86-7.77,7.71-$ $7.58,7.51-7.45,2.23-2.01,1.58-1.53,1.28-1.06,0.85-$ 0.73. ${ }^{13} \mathrm{C} \mathrm{NMR}\left(\mathrm{CDCl}_{3}, \mathrm{ppm}\right) \delta: 152.02,140.73,140.23$, 129.01, 126.37, 121.75, 121.65, 120.21, 55.55, 55.37, $40.57,31.69,31.15,29.89,29.84,24.07,23.95,22.78$, 14.25.

Poly(fluorene-co-1,3-diphenylimidazol-2-thione) 9. In a nitrogen atmosphere, potassium tert-butoxide $(0.200 \mathrm{~g}$, $1.782 \mathrm{mmol}$ ) was added to a suspension of sulfur $(0.086 \mathrm{~g}, 2.674 \mathrm{mmol})$ in $30 \mathrm{ml}$ of THF, and the resulting suspension was stirred at room temperature for $10 \mathrm{~min}$. $0.500 \mathrm{~g}$ of poly(fluorene-co-1.3-diphenylimidazolium chloride) 7 in $20 \mathrm{ml}$ of THF were added slowly to the suspension and the reaction mixture was stirred at $296 \mathrm{~K}$ for $24 \mathrm{~h}$. The volatiles were removed under vacuum, and the residue was extracted with warm benzene. The benzene solution was filtered through a glass filter. The filtrate was concentrated by rotary evaporation. The solution was added slowly to a stirred solution containing $100 \mathrm{ml}$ of methanol and $100 \mathrm{ml}$ of acetone. The polymer fibers were collected by filtration and washed with methanol. The polymer weighed $0.467 \mathrm{~g}$ (approximately $94 \%$ yield). ${ }^{1} \mathrm{H}$ NMR $\left(\mathrm{CDCl}_{3}, \mathrm{ppm}\right) \delta$ : 7.85-7.78, 7.72-7.56, 7.51-7.44, 7.39-7.29, 2.21-1.74, $1.31-1.04,0.90-0.67 .{ }^{13} \mathrm{C}$ NMR $\left(\mathrm{CDCl}_{3}, \mathrm{ppm}\right) \delta: 152.04$, $140.76,140.26,140.24,140.13,126.38,125.41,125.01$, $121.72,121.32,120.19,55.62,40.59,40.57,32.01$,
$31.70,30.26,29.92,29.89,29.44,24.14,24.08,24.01$, $22.81,22.78,14.28,14.25$.

\section{Results and Discussion}

\subsection{Synthesis and Structural Characterization}

Reaction monomer 1,3-bis(4-bromophenyl) imidazolium chloride $\mathbf{4}$ was synthesized using a procedure previously reported [10]. As shown in Scheme 1, reaction monomer 1,3-bis(4-bromophenyl)imidazolium chloride $\mathbf{4}$ was synthesized by reacting glyoxal 1, 4-bromoaniline $\mathbf{2}$ with $p$-formaldehyde $\mathbf{3}$ in an aqueous $\mathrm{HCl}$ solution.

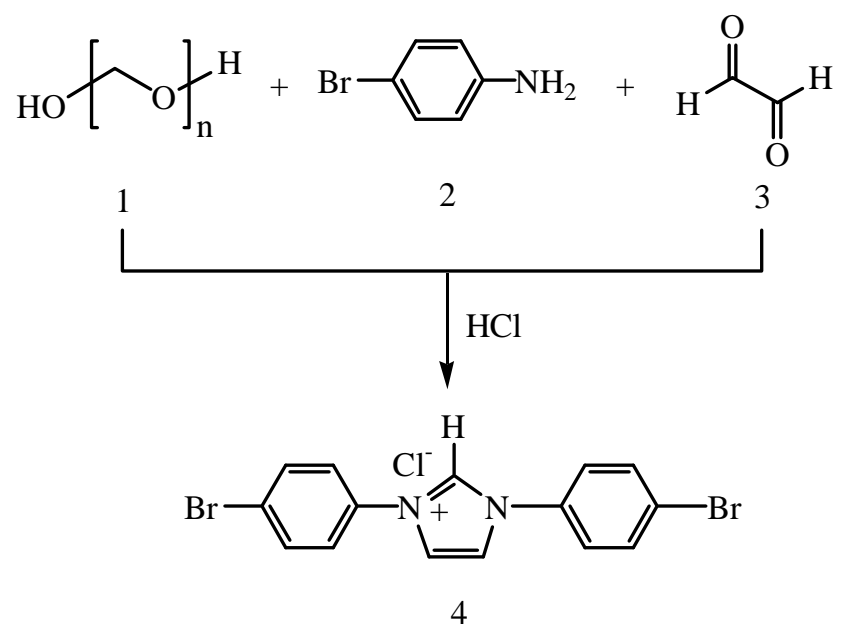

Scheme 1. Synthetic route of monomer 4

The structure was characterized by ${ }^{1} \mathrm{H}$ NMR and ${ }^{13} \mathrm{C}$ NMR spectroscopy, and mass spectrometry. In the mass spectrum, the base peak was observed at $379\left(\mathrm{M}^{+}-\right.$ $\mathrm{Cl})$ and a typical fragmentation pattern was noted. The ${ }^{1}$ H NMR spectra of the 1,3-bis(4-bromophenyl) imidazolium chloride 4 showed the following $\delta$ values: $7.48(d, 2 \mathrm{H}), 7.71(d, 4 \mathrm{H})$ and $7.79(d, 2 \mathrm{H}) \mathrm{ppm}$ for the $\mathrm{H}$ atoms on the benzene ring, and $8.31(s, 2 \mathrm{H}), 10.13(s, 1 \mathrm{H})$ $\mathrm{ppm}$ for the $\mathrm{H}$ atoms on the imidazol ring. The ${ }^{13} \mathrm{C}-\mathrm{NMR}$ spectra of monomer 4 showed the following $\delta$ values: 126.28 136.52 ppm for the $\mathrm{C}$ atoms of the phenyl ring, $124.14 \mathrm{ppm}$ for the C-2 atom of the imidazol ring, and $125.78,125.83 \mathrm{ppm}$ for the C-4 and C-5 atoms of the imidazol ring.

Poly(fluorene-co-1,3-diphenylimidazolium chloride) 7 was synthesized by Suzuki cross-coupling polymerization between 1,3-bis(4-bromophenyl) imidazolium chloride 4, 9,9-dioctylfluorene-2,7-diboronic acid bis(1,3-propanediol)ester 5 and 2,7-dibromo-9,9dioctylfluorene 6. Scheme 2 shows the synthetic route for copolymer 7. Copolymer 7 was characterized and 


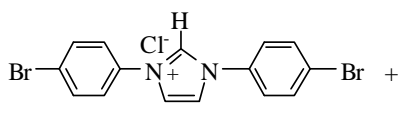

4

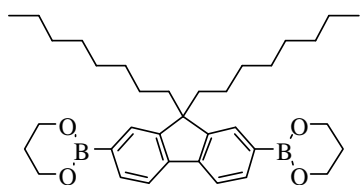

5

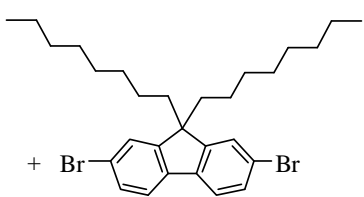

6

1) $\mathrm{Pd}(0)$, Allquat $336,2 \mathrm{M} \mathrm{Na}_{2} \mathrm{CO}_{3}$

2) 2-(4-bromophenyl)-5-phenyl-1,3,4-oxadiazole

3) 2-thiophene boronic acid

$60 \mathrm{~h}, 363 \mathrm{~K}$

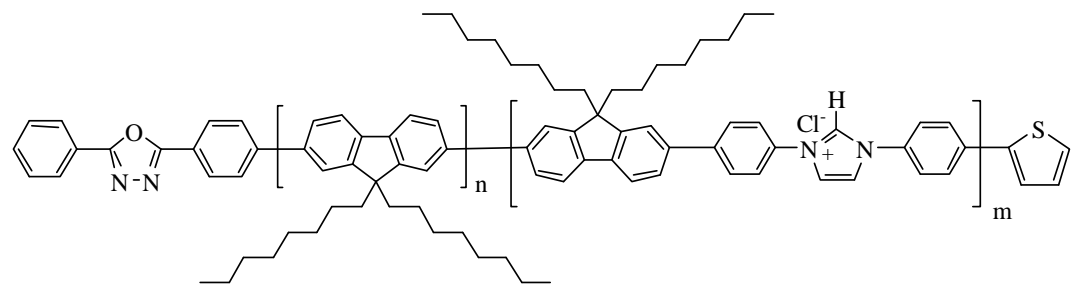

7

Scheme 2. Synthetic route of poly(fluorene-co-1,3-diphenylimidazolium chloride) 7
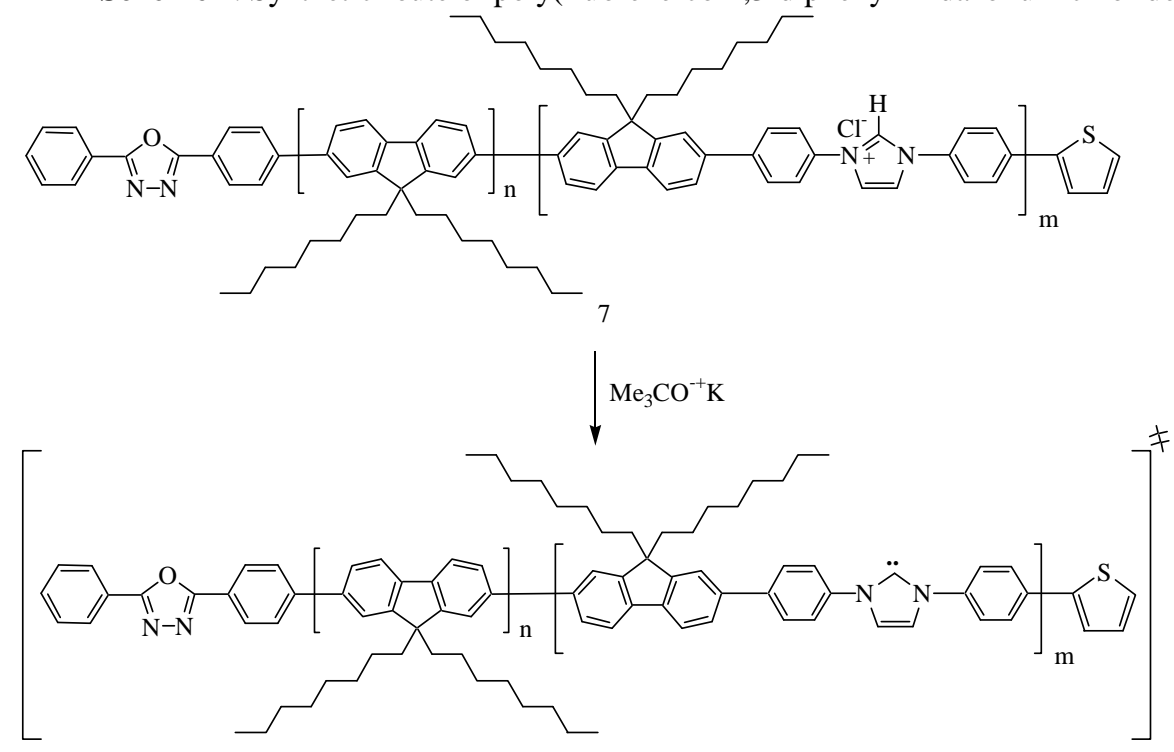

Sulfur

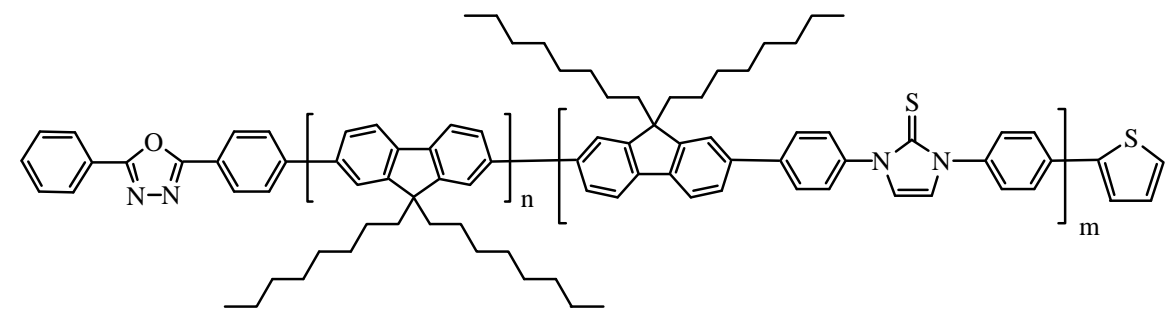

Scheme 3. Synthetic route of poly(fluorene-co-1,3-diphenylimidazol-2-thione) 9 


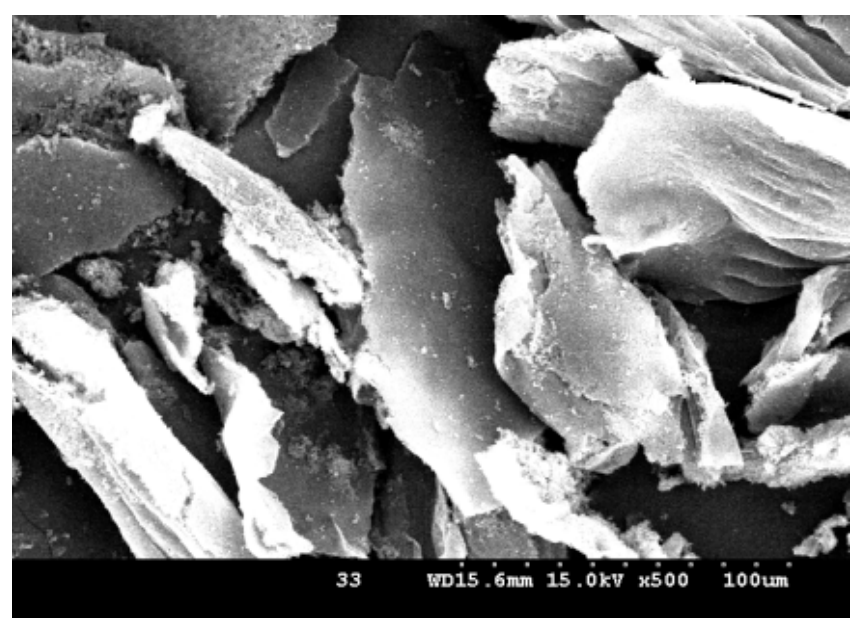

a)

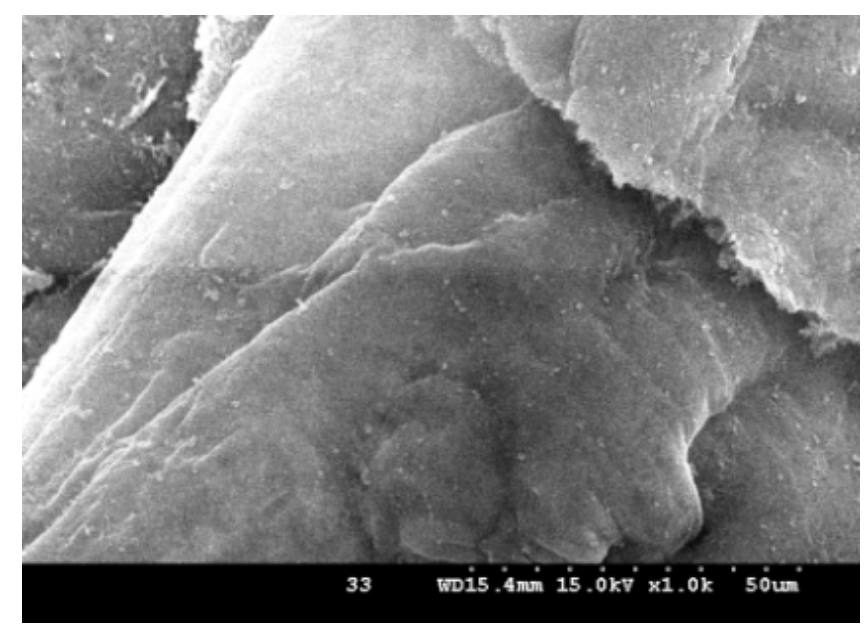

b)

Fig. 1. SEM images of copolymer 7: magnification of 500x (a) and 1,000x (b)

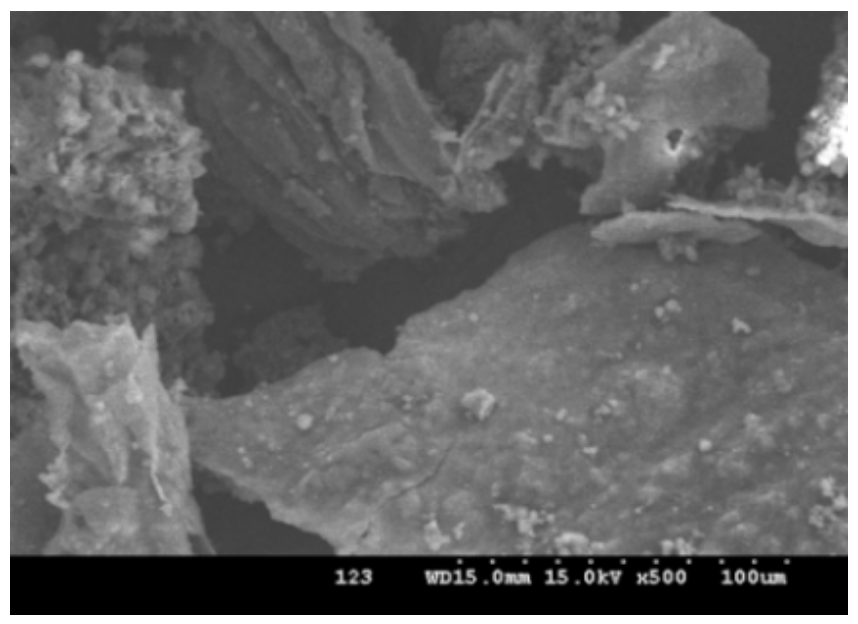

a)

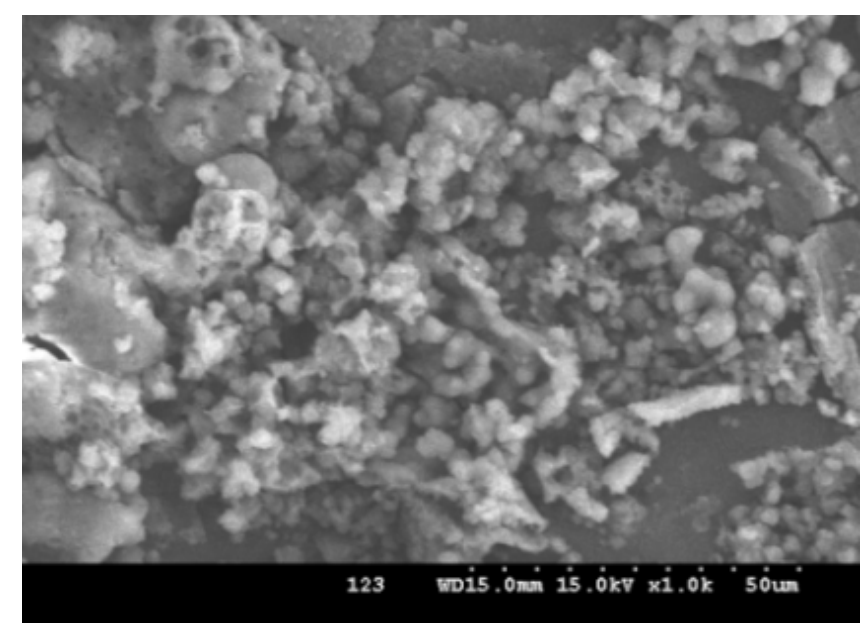

b)

Fig. 2. SEM images of copolymer 9: magnification of 500x (a) and 1,000x (b)

verified by ${ }^{1} \mathrm{H}$ NMR and ${ }^{13} \mathrm{C}$ NMR spectroscopy, and SEM-EDX. The ${ }^{1} \mathrm{H}$ NMR spectra of copolymer $\mathbf{7}$ showed the following $\delta$ values: approximately 7.45$7.86 \mathrm{ppm}$ for $\mathrm{H}$ atoms on the phenyl ring and the imidazole ring, and $0.73-1.28 \mathrm{ppm}$ for the $\mathrm{H}$ atoms on the octyl groups. From the ${ }^{13} \mathrm{C}$ NMR spectra, signals were observed at approximately $121.65-152.02 \mathrm{ppm}$ for the $\mathrm{C}$ atoms of the phenyl ring and the imidazole ring, approximately $48-14 \mathrm{ppm}$ for the octyl groups, and $55 \mathrm{ppm}$ for the $\mathrm{C} 9$ atoms of the fluorene ring.

In order to determine the ratio of the atoms present in the compound, this study did an EDX measurement. From the results of the EDX measurement, copolymer 7 was found to be a substance which mostly consisted of carbon. Figure 1 shows the SEM images of copolymer 7.

Poly(fluorene-co-1,3-diphenylimidazol-2-thione) 9 was synthesized by reacting copolymer 7 with sulfur in the presence of potassium tert-butoxide. In this reaction, the imidazol-2-ylidene derivative (carbene) $\mathbf{8}$ formed by deprotonation of the imidazolium salts 7 with potassium tert-butoxide presumed to be the intermediate. Scheme 2 shows the synthetic route for copolymer 9. Copolymer 9 was characterized and verified by ${ }^{1} \mathrm{H}$ NMR and ${ }^{13} \mathrm{C}$ NMR spectroscopy, and SEM-EDX. The ${ }^{1} \mathrm{H} N \mathrm{MR}$ spectra of copolymer 9 showed the following $\delta$ values: approximately 7.29-7.85 ppm for $\mathrm{H}$ atoms on the phenyl ring and the imidazole ring, and $0.67-1.31 \mathrm{ppm}$ for the $\mathrm{H}$ atoms on the octyl groups. From the ${ }^{13} \mathrm{C}$ NMR spectra, signals were observed at approximately 120.19-152.04 ppm for the $\mathrm{C}$ atoms of the phenyl ring and the imidazole ring, approximately $14.25-40.59 \mathrm{ppm}$ for the octyl groups, and $55.62 \mathrm{ppm}$ for the $\mathrm{C} 9$ atoms of the fluorene ring.

In order to determine the degree of substitution of the sulfur atom, an EDX measurement was done. From 
the results of the EDX measurement, it was found that copolymer 9 mostly consisted of carbon atoms and sulfur atoms were composed of 10.79 wt $\%$ and 4.80 at $\%$. Even though the reactant 7 contained sulfur atoms, they were present in very small amount as the atoms included in the terminal group. The EDX measurement of reactant 7 showed that sulfur atoms were almost not present. This result shows that the sulfur atoms were reacted with reactant 7. Fig. 2 shows the SEM images of copolymer 9.

\subsection{Physical and Optical Properties}

The molecular weight of copolymers 7 and 9 were measured by calibrated with polystyrene standards. Table 1 presents the weight-average molecular weight $\left(M_{w}\right)$, number-average molecular weight $\left(M_{n}\right)$, and polydispersity index (PDI) of the copolymers. Copolymer 7 exhibited an $M_{w}$ of 16,337; $M_{n}$ of 10,229, and PDI of 1.59 . Copolymer 7 had a relatively low molecular weight. The reason the molecular weight is not high is believed to be associated with the solubility of copolymer 7. Copolymer 7 is the salt form of an organic substance. As molecular weight increases, the solubility in organic solvents decreases. In other words, copolymer $\mathbf{7}$ is precipitated as a crystal if it is over a certain molecular weight during the reaction. Thus, it is difficult to have this reaction with a monomer. It is thought that this is the reason it has a relatively low molecular weight. The copolymer 9 exhibited an $M_{w}$ of 18,$625 ; M_{n}$ of 10,439 , and PDI of 1.78 .

The thermal properties of the copolymers were measured by TGA and DSC under a nitrogen atmosphere. The glass transition temperature $\left(T_{g}\right)$ of copolymers 7 and 9 were approximately 371 and $418 \mathrm{~K}$, respectively. The glass transition temperature of $\mathbf{9}$ was higher than that of the copolymer 7. Thermogravimetric analysis (TGA) showed the excellent thermal stability of the resulting polymers. Initial weight loss $(5 \%)$ was observed around $700 \mathrm{~K}$, with the main decomposition occurring around $760 \mathrm{~K}(50 \%)$. The initial degradation temperature $\left(T_{i d}\right)$ of 7 and 9 were 702 and $705 \mathrm{~K}$, respectively. As shown in Fig. 4, the TGA thermograms of copolymers $\mathbf{7}$ and 9 exhibited two weight-loss plateaus. At lower temperatures, almost no weight loss was observed. The side chain in copolymer 7 decomposed first at approximately $623-783 \mathrm{~K}$; its onset temperature for thermal bond cleavage was approximately $702 \mathrm{~K}$. The polymer backbone was subjected to decomposition at approximately 783-1100 $\mathrm{K}$, where the onset temperature for thermal bond cleavage was at $823 \mathrm{~K}$. The side chain in the copolymer 9 decomposed first at approximately $633-793 \mathrm{~K}$; its onset temperature for thermal bond cleavage was approximately $705 \mathrm{~K}$.

The optical properties of the copolymers were analyzed by UV-Vis and PL spectroscopy. Fig. 5 shows the UV-Vis and photoluminescence (PL) spectra of copolymers 7 and 9, which were measured in methylene chloride at room temperature. The PL spectra of the copolymers in thin film were taken under excitation of the $325 \mathrm{~nm}$ line of $\mathrm{He}-\mathrm{Cd}$ laser. Thin films of the copolymers were prepared from a toluene solution by spin-coating onto a quartz plate. The copolymers in this study emitted in the blue region with a maximum around $440 \mathrm{~nm}$. Copolymer 7 showed an absorption band at $\lambda_{\max }=367 \mathrm{~nm}$ and a maximum emission band at $434 \mathrm{~nm}$. Copolymer 9 showed an absorption band at $\lambda_{\max }=365 \mathrm{~nm}$ (shoulder at $395 \mathrm{~nm}$ ). The intense absorption peaks below $370 \mathrm{~nm}$ are attributed to the $\pi \rightarrow \pi^{*}$ transition of aromatic rings, and side peaks of about $395 \mathrm{~nm}$ can be assigned to the absorption of the $\mathrm{C}=\mathrm{S}$ bond on to the imidazol ring. The emission spectrum of copolymer $9\left(\lambda_{\max }=449 \mathrm{~nm}\right)$ shows a red shift of $15 \mathrm{~nm}$ compared to that of the host copolymer 7. This is probably due to the interruption of delocalization of the $\pi$-electrons along the polymer backbone by the $\mathrm{C}=\mathrm{S}$ bond. From the onset of the absorption peak, the optical band gap of copolymer 9 was estimated to be $2.91 \mathrm{eV}$, which is a little less than that of the host copolymer $7(3.06 \mathrm{eV})$.

Table 1

Physical and optical properties of copolymers 7 and 9

\begin{tabular}{|c|c|c|c|c|c|c|c|c|}
\hline Polymer & $M_{n}{ }^{\mathrm{a}}$ & $M_{w}{ }^{\mathrm{a}}$ & $\begin{array}{c}P D I^{\mathrm{a}} \\
\left(M_{\mathrm{w}} / M_{n}\right)\end{array}$ & $\begin{array}{c}T_{\mathrm{g}}, \\
\mathrm{K}\end{array}$ & $\begin{array}{c}T_{\mathrm{d}}{ }^{\mathrm{b}}, \\
\mathrm{K}\end{array}$ & $\begin{array}{c}\lambda_{\max } a b s, \\
\mathrm{~nm}\end{array}$ & $\begin{array}{c}\lambda_{P L}, \\
\mathrm{~nm}\end{array}$ & $\begin{array}{c}E_{g}{ }^{\mathrm{c}}, \\
\mathrm{eV}\end{array}$ \\
\hline $\mathbf{7}$ & 10229 & 16337 & 1.59 & 371 & 702 & 367 & 434 & 3.06 \\
\hline $\mathbf{9}$ & 10439 & 18629 & 1.78 & 418 & 705 & 365 & 449 & 2.91 \\
\hline
\end{tabular}

Notes: ${ }^{a} M_{n}, M_{w}$ and PDI of the polymers were determined by gel permeation chromatography (GPC) using polystyrene standards. ${ }^{\mathrm{b}}$ Temperature of $5 \%$ weight loss measured by TGA in nitrogen. ${ }^{\mathrm{C}}$ Estimated from the onset of the absorption edge responsible for the copolymers. 


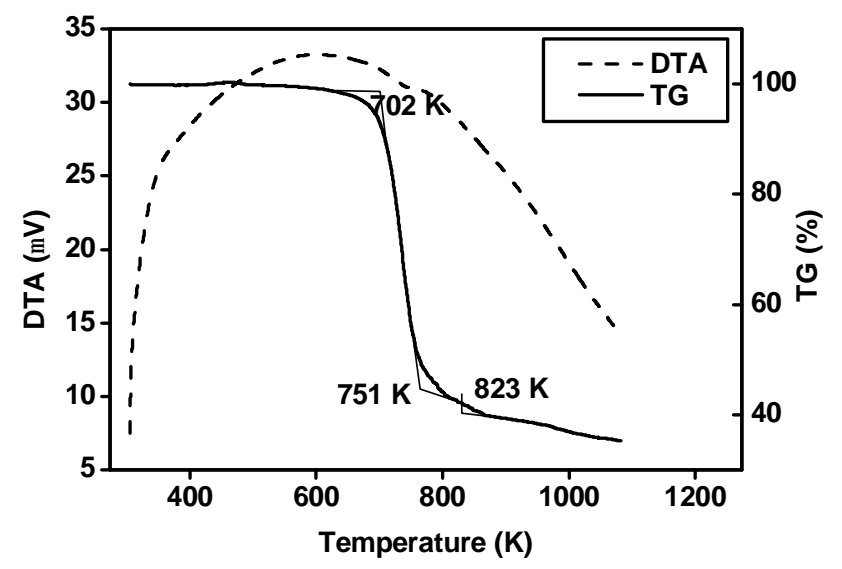

a)

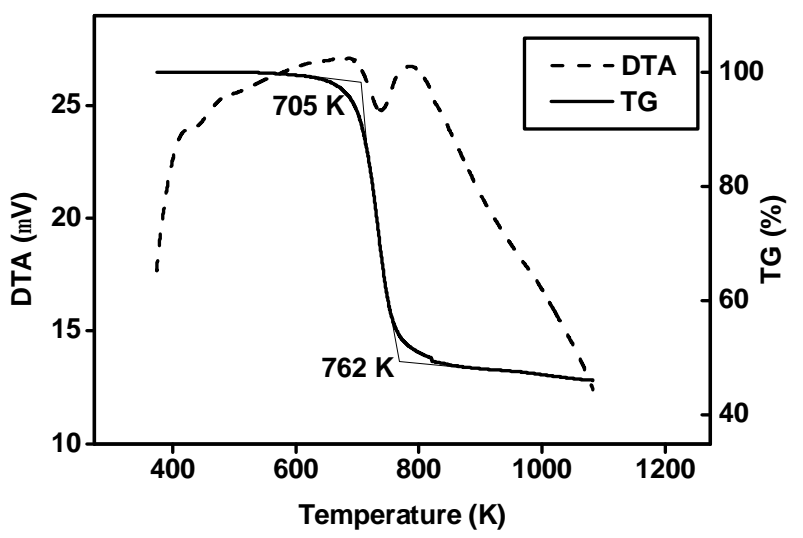

b)

Fig. 4. TGA thermograms of the copolymers 7 (a) and 9 (b)

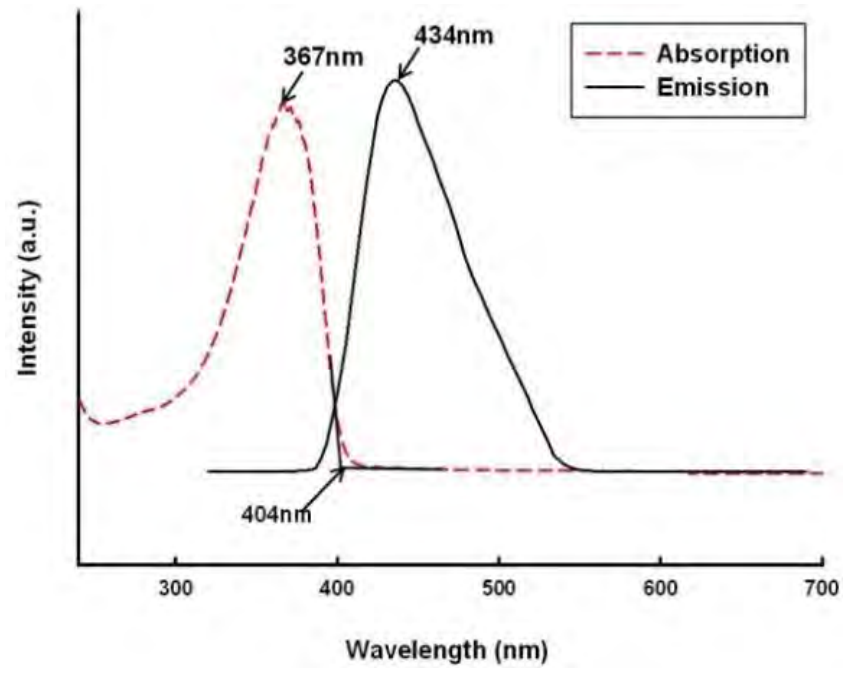

a)

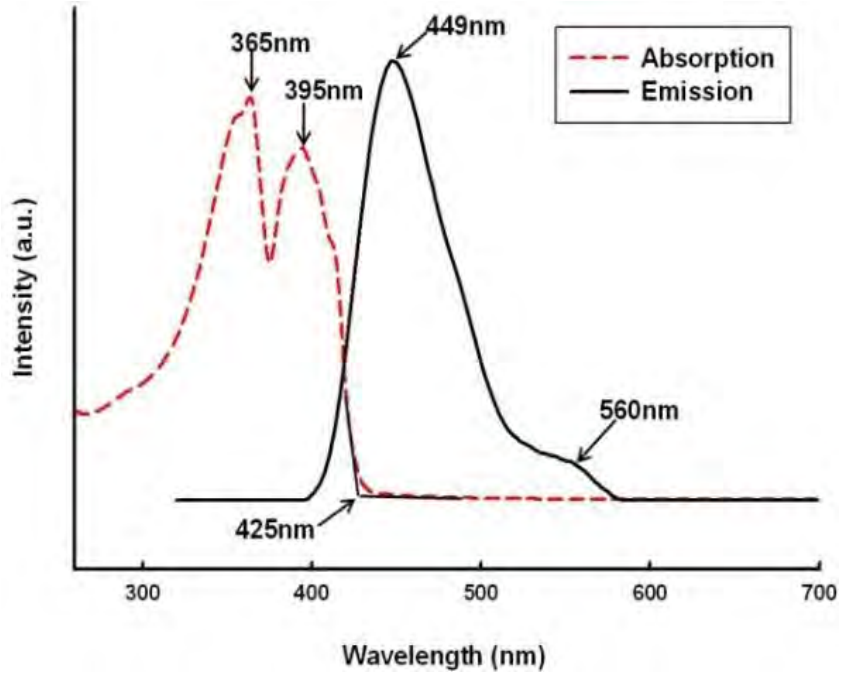

b)

Fig. 5. UV-vis and PL spectra of copolymers 7 (a) and 9 (b)

\section{Conclusions}

In this study, we synthesized new PAF derivatives [poly(fluorene-co-1,3-diphenylimidazolium chloride) 7 and poly(fluorene-co-1,3-diphenylimidazol-2-thione) 9] with high thermal stability and their physical and optical properties were investigated. Reaction monomer 1,3bis(4-bromophenyl)imidazolium chloride $\mathbf{4}$ was synthesized by the reaction of glyoxal 1, 4-bromoaniline $\mathbf{2}$ with $p$-formaldehyde $\mathbf{3}$ in an aqueous $\mathrm{HCl}$ solution. Poly(fluorene-co-1.3-diphenylimidazolium chloride) 7 was synthesized by Suzuki cross-coupling polymerization between 1,3-bis(4-bromophenyl)imidazolium chloride 4, 9,9-dioctylfluorene-2,7-diboronic acid bis(1,3-propanediol)ester 5 and 2,7-dibromo-9,9dioctylfluorene 6. Poly(fluorene-co-1.3-diphenylimidazol-2-thione) 9 was synthesized from the reaction of copolymer 7 with sulfur in the presence of potassium tert-butoxide. The obtained polymers were characterized by ${ }^{1} \mathrm{H}$ NMR, ${ }^{13} \mathrm{C}$ NMR, DSC, TGA and GPC. In order to determine the degree of substitution of sulfur atoms, EDX measurements were done. From the results of the EDX measurements, it was found that copolymer 9 mostly consisted of carbon atoms and the sulfur atoms were composed of $10.79 \mathrm{wt} \%$ and 4.80 at $\%$.

The glass transition temperatures $\left(T_{g}\right)$ of 7 and 9 were found to be 371 and $418 \mathrm{~K}$, respectively. The glass transition temperature of 9 was higher than that of the copolymer 7. Thermogravimetric analysis (TGA) showed the excellent thermal stability of the resulting polymers. An initial weight loss (5\%) was observed around $693 \mathrm{~K}$, with the main decomposition occurring around $760 \mathrm{~K} \quad(50 \%)$. The initial degradation 
temperature $\left(T_{i d}\right)$ of 7 and 9 were 702 and $705 \mathrm{~K}$, respectively. The main absorption peaks in the UV-Vis spectra of 7 and 9 were observed at 367 and $365 \mathrm{~nm}$, respectively. The copolymers in this study emitted in the blue region with a maximum around $440 \mathrm{~nm}$. The emission spectra of copolymer 9 showed a red shift compared to that of the host copolymer 7. The PL spectra of 7 and 9 in the thin film showed a maximum emission band at 434 and $449 \mathrm{~nm}$, respectively. From the onset of the absorption peak, the optical band gap of copolymer 9 was estimated to be $2.91 \mathrm{eV}$, which is a little less than that of the host copolymer $7(3.06 \mathrm{eV})$.

\section{Acknowledgments}

This research was supported by Kyungpook National University Research Fund, 2012.

\section{References}

[1] Ranger M. and Leclerc M.: Chem. Commun., 1997, 1597.

[2] Setayesh S., Marsitzky D. and Mullen K.: Macromolecules, 2000, 33, 2016.

[3] Setayesh S., Grimsdale A., Weil. T. et al.: J. Am. Chem. Soc., 2001, 123, 946.

[4] Lee J., Klaerner G. and Miller R.: Chem. Mater., 1999, 11, 1083.

[5] Ranger M., Rondeau D. and Leclerc M.: Macromolecules, 1997, 30, 7686.

[6] Fukuda M., Sawada K. and Yoshino K.: J. Polym. Sci. A, 1993 , 31, 2465

[7] Chou C. and Shu C.: Macromolecules, 2002, 35, 9673.

[8] Renqiang Y., Renyu T., Jingai Y. et al: Macromolecules, 2005, 38, 244.

[9] Oh D., Lee W. and Park J.: Chem. \& Chem. Techn., 2013, 7, 47.

[10] Murray R., Trozzolo A., Wasserman E. and Yager W.: J. Am. Chem. Soc., 1962, 84, 3213.

[11] Arduengo A. and Wilmington D.: Pat US 5077414, Publ. Dec. 31, 1991.

[12] Arduengo A., Harlow R., Kline M. and Dias H.: J. Am. Chem. Soc., 1992, 114, 5530.
[13] Dixon D. and Arduengo A.: J. Phys. Chem., 1991, 95, 4180. [14] Huang J., Stevens E., Nolan S. and Petersen J.: J. Am. Chem. Soc., 1999, 121, 2674.

[15] Downing S., Guadano S., Pugh D. et al.: Organometallics., 2007, 26, 3762.

[16] Arduengo A.: Acc. Chem. Res., 1999, 32, 913.

[17] Herrmann W. and Kocher C.: Angew. Chem.. Int. Ed. Engl., 1997, 36, 2162.

[18] Lorber C. and Vendier L.: Organometallics., 2008, 27, 2774.

[19] Kuhn N., Kratz T., Blaer D. and Boese R.: Inorganica Chimica Acta., 1995, 238, 179.

[20] Arduengo A. and Wilmington D.: Pat US 5162482, Publ. Nov. 10, 1992.

[21] Regitz M.: Angew. Chem., 1991, 103, 691.

[22] Kuhn N., Kratz T., Blaser D. and Boese R.: Chem. Ber., 1995, 128, 245.

[23] Jianfeng L., Carola S., Sebastian M. et al.: Z. Anorg. Allg. Chem., 2010, 636, 511.

[24] Benac B., Burgess E. and Arduengo A.: Org. Synth., 1986, 64, 92.

\section{СИНТЕЗ І ХАРАКТЕРИСТИКА ФЛУОР-ІМЦДАЗОЛЬНИХ КОПОЛІМЕРІВ}

Анотація. Синтезовано нові похідні з високою термічною стабільністю: полі(флуор-ко-1,3-дифенілімідазолін хлорид) (7) та полі(флуор-ко-1,3-дифенілімідазол-2-тіон) (9). Досліджено їх фізичні та оптичні властивості. Отримано характеристику синтезованих полімерів за допомогою ${ }^{1}$ Н ЯМР, ${ }^{13}$ С ЯМР, диференційної скануючої калориметрії, термогравіметричного аналізу (ТГА), хроматографії та растрової електронної мікроскопії. За результатами ТГА визначено відмінну термостабільність одержуваних полімерів. Показано, щчо вихідна втрата ваги (5\%) спостерігається близько $700 \mathrm{~K}$, а основний розклад відбувається біля $760 \mathrm{~K}$ (50\%). Температура склування сполуки (9) є вищою порівняно 3 кополімером (7). Спектри випромінювання кополімеру (9) показали зміщення $у$ червону область $y$ порівнянні 3 первинним кополімером (7). Для кополімерів (7) $i$ (9) визначено оптичну ширину забороненої зони від початку поглинання кополімерів, яка становить 3,06 і 2,91 еВ відповідно.

Ключові слова: провідний полімер, поліалкілфлуор, кополімер, імідазол-2-іліден, карбен. 